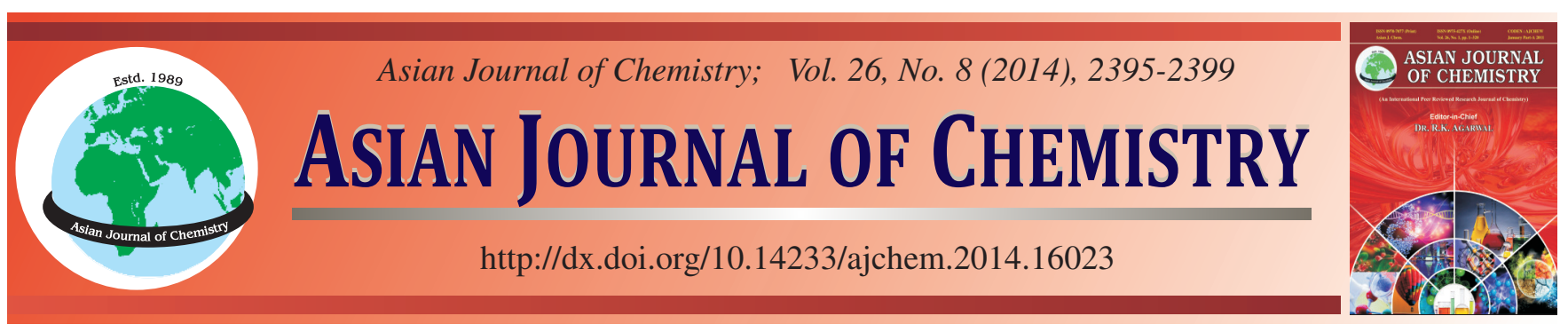

\title{
Determination of Stability Constants of Mixed Ligand Complexes of Picolinic Acid and Other Bioactive Ligands with Zn(II) by Potentiometric Titration Method
}

\author{
Nada M. Arishy ${ }^{1}$, Reda A. Ammar ${ }^{1,2, *}$ and Abdulrhman Al-Warthan ${ }^{1}$
}

${ }^{1}$ Department of Chemistry, College of Science, King Saud University, P.O. Box 22452, Riyadh 11495, Saudi Arabia

${ }^{2}$ Department of Chemistry, College of Science, Al Azhar University, Cairo, Egypt

*Corresponding author: E-mail: rammar@ksu.edu.sa

Received: 9 July 2013;

Accepted: 5 November 2013;

Published online: 15 April 2014;

AJC-15033

\begin{abstract}
The stability constants of ternary complexes of $\mathrm{Zn}$ (II) with picolinic acid as primary ligand and some of bioactive ligands (e.g., amino acids and peptides) as secondary ligand were determined $\mathrm{pH}$-metrically at $25^{\circ} \mathrm{C}$ and ionic strength $0.1 \mathrm{~mol} / \mathrm{L} \mathrm{NaNO}_{3}$ in water solution. The possible formation of ternary complexes via simultaneous mechanisms has been confirmed by comparison with constructed theoretical curves. The stability of each ternary complexes was also investigated and compared with those of the corresponding binary complexes in terms of the $\Delta \log \mathrm{K}$ parameter. In addition, the concentration distribution of the complexes formed in solution was evaluated.
\end{abstract}

Keywords: Picolinic acid, Mixed ligand complexes, $\Delta \log \mathrm{K}$, Stability constants, Potentiometric studies.

\section{INTRODUCTION}

Picolinic acid $(\mathrm{P})$ is, chemically, pyridine-2-carboxalic acid. It is a six-member ring structure compound (Fig. 1) that has been detected in a many of the biological systems ${ }^{1}$. The picolinic acid is present in many natural products and acts as a bidentate ligand by (N, COO-) coordination for many metal ions $^{2}$. Examples include, cobalt(III) ${ }^{3}$, copper(II $)^{4}$, chromium(VI) ${ }^{5}$, manganese(II) $)^{6}$, vanadium(III) ${ }^{7}$ and palladium(II) ${ }^{8}$. Metallic complexes of picolinic acid have received increasing attention in last few decades ${ }^{2}$ because of their variety applications in the chemical and pharmaceutical industry ${ }^{9}$. For example, chromium picolinate increases and regulates the secretion of insulin ${ }^{10,11}$. Also, zinc picolinate has a healing effect against herpes simplex virus ${ }^{12}$.

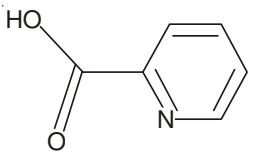

Fig.1. Structure of picolinic acid

Furthermore, the stability constants of zinc(II)-picolinic acid $^{13}$, zinc(II)-amino acid and zinc(II) peptides complexes ${ }^{14}$ were previously studied. Until now, there are no reports on the speciation of ternary $\mathrm{Zn}$ (II)-picolinic acid complexes with amino acids and peptides by potentiometric titration. In the present work, equilibrium and the stability constants of mixed complexes composed of picolinic acid and bioactive ligands (amino acid and peptide) with $\mathrm{Zn}$ (II) were determined using potentiometric titration in water solution at $25^{\circ} \mathrm{C}$ and an ionic strength (I) of $0.1 \mathrm{~mol} / \mathrm{L}\left(\mathrm{NaNO}_{3}\right)$.

\section{EXPERIMENTAL}

All chemicals in this work were of guaranteed grade and used without further purification. Picolinic acid was obtained from sigma. All the amino acids, related compounds and peptides used are glycine, alanine, valine, proline, $\beta$-phenylalanine, methionine, isoleucine, glutamic acid, threonine, serine, ornithine, cysteine, histidine, histamine- $2 \mathrm{HCl}$, pencill-amine, imidazole, mercaptoethanol methylamine, glycyl glycine, glycinamide and glutamine were provided by BDH-Biochemicals Ltd. The zinc content of solutions was determined by complexometric EDTA titrations ${ }^{15}$. Threonine, serine, ornithine, cysteine, histidine and pencillamine solutions were prepared in the protonated form by dissolution in two equivalents of nitric acid. All stock solutions of $\mathrm{NaNO}_{3}$ and $\mathrm{HNO}_{3}$ (Merck) were prepared in deionized water. $\mathrm{Zn}\left(\mathrm{NO}_{3}\right)_{2} \cdot 6 \mathrm{H}_{2} \mathrm{O}$ and $\mathrm{NaNO}_{3}$ were provided by BDH-Biochemicals Ltd. The ionic strength of each solution was adjusted to $0.10 \mathrm{~mol} / \mathrm{L} \mathrm{NaNO}_{3}$. Carbonate-free $\mathrm{NaOH}$ (titrant) was prepared and standardized against a potassium hydrogen phthalate solution.

All the $\mathrm{pH}$-measurements were performed with a Metrohm 211 microprocessor (Hanna, Romania) in $0.1 \mathrm{M}$ ionic strength at $298 \mathrm{~K}$ temperature. The microprocessor and electrode were calibrated with standard buffer solutions, prepared according to NBS specification ${ }^{16}$. 
Procedure and measurements: The dissociation constants of the primary ligand picolinic acid and other ligands were determined potentiometrically by titrating the ligand $(40 \mathrm{~mL})$ solution $\left(1 \times 10^{-2} \mathrm{~mol} / \mathrm{L}\right)$. All titrations, $\mathrm{HNO}_{3}$ solution was added in this work to ensure full protonation of ligands. The formation constant of the binary complex was determined using potentiometric data obtained from mixtures $(40 \mathrm{~mL})$ of zinc ion $\left(5 \times 10^{-3} \mathrm{~mol} / \mathrm{L}\right)$ and the ligand in the concentration ratio of $1: 1$ and 1:2 (zinc:ligand) for picolinic acid, amino acids and peptides. Finally, the stability constants of the ternary complexes were determined by titrating $40 \mathrm{~mL}$ of a solution mixture contained equivalent amounts of zinc(II) ion, picolinic acid and the other ligand $\left(1 \times 10^{-2} \mathrm{~mol} / \mathrm{L}\right)$, giving rise to molar ratios of $1: 1: 1$ at $\mathrm{I}=0.1 \mathrm{~mol} / \mathrm{L}\left(\mathrm{NaNO}_{3}\right)$ at $25^{\circ} \mathrm{C}$ in water solution.

Data processing: The stability constants and stoichiometries of the complex species formed in water solutions were determined through the study of various possible composition models for the systems studied. In this study, all the calculations were performed for the dissociation and the complex formation constants using the computer program HYPERQUAD ${ }^{17}$ and the speciation as a function of $\mathrm{pH}$ using the computer program $\mathrm{HYSS}^{18}$.

\section{RESULTS AND DISCUSSION}

The dissociation constants of the ligands were determined in water solution and under the experimental conditions $\left(25^{\circ} \mathrm{C}\right.$, $\mathrm{I}=0.1 \mathrm{~mol} / \mathrm{L} \mathrm{NaNO}_{3}$ ), which were also used for determining the stability constants of the $\mathrm{Zn}$ (II) complexes and the results are given in Table- 1 .

Dissociation constants of picolinic acid: The calculated acid dissociation constants of the picolinic acid, expressed as $\mathrm{pK}_{\mathrm{a}}$ values, were given in Table-1. In acid medium, the first protonation constant refers to the of the pyridine $\left(\mathrm{pKa}_{1}=5.22\right)$ and the second to the carboxylic acid $\left(\mathrm{pKa}_{2}=1.52\right)$. These results obtained are consistent with previous investigations undertaken for related systems ${ }^{19}$.

Binary complexes: The titration curve of the $\mathrm{Zn}$ (II)-picolinic acid complex is markedly lower than the picolinic acid titration curve, indicating formation of $\mathrm{Zn}$ (II) complexes by displacement of protons (Fig. 2). In the binary systems of ( $\mathrm{Zn}$ (II)picolinic acid) the selected model with the best statistical fit was found to consist of $\mathrm{Zn}$ (picolinic acid) and $\mathrm{Zn}$ (picolinic acid) $)_{2}$, where the picolinic acid binds the zinc ion by N-pyridine and O-carboxylato atoms. Beside, the selected model of zinc with bioligand was found to consist of $\mathrm{Zn}(\mathrm{L}), \mathrm{Zn}(\mathrm{L})_{2}$ and $\mathrm{Zn}(\mathrm{L})_{3}$ species.

Ternary complexes: In general, the overall formation constant can be written as follows (charges are omitted for simplicity):

$$
\begin{gathered}
1(\mathrm{zn})+\mathrm{p}(\mathrm{P})+\mathrm{q}(\mathrm{L})+\mathrm{r}(\mathrm{H}) \leftrightarrow(\mathrm{Zn})_{1}(\mathrm{P})_{\mathrm{p}}(\mathrm{L})_{\mathrm{q}}(\mathrm{H})_{\mathrm{r}} \\
\beta_{\mathrm{lpqr}}=\frac{\left[\mathrm{zn}_{1} \mathrm{P}_{\mathrm{p}} \mathrm{L}_{\mathrm{q}} \mathrm{H}_{\mathrm{r}}\right]}{[\mathrm{Zn}]^{1}[\mathrm{P}]^{\mathrm{p}}[\mathrm{L}]^{\mathrm{q}}[\mathrm{H}]^{\mathrm{r}}}
\end{gathered}
$$

Ternary complexes involving $\mathbf{Z n}($ II)-picolinic acidamino acids: The possible formation of ternary complexes via simultaneous mechanisms has been confirmed by compa-

\begin{tabular}{|c|c|c|c|c|c|}
\hline \multicolumn{6}{|c|}{$\begin{array}{c}\text { TABLE-1 } \\
\text { STABILITY CONSTANTS OF BINARY SYSTEMS Zn(II)-P, } \\
\text { Zn(II)-L AND PROTON-ASSOCIATION CONSTANTS } \\
\text { AT } 25^{\circ} \mathrm{C} \text { AND I }=0.1 \mathrm{~mol} ; \mathrm{L}=\mathrm{NaNO}_{3}\end{array}$} \\
\hline System & $\mathrm{L}$ & $\mathrm{P}$ & $q$ & $\mathrm{r}^{\mathrm{a}}$ & $\log 10 \beta^{b}$ \\
\hline \multirow{4}{*}{ Picolinic acid (P) } & 0 & 0 & 1 & 1 & $5.22(0.008)$ \\
\hline & 0 & 0 & 1 & 2 & $6.74(0.04)$ \\
\hline & 1 & 0 & 1 & 0 & $5.12(0.02)$ \\
\hline & 1 & 0 & 2 & 0 & $9.42(0.03)$ \\
\hline \multirow{4}{*}{ Glycine } & 0 & 0 & 1 & 1 & $9.64(0.01)$ \\
\hline & 0 & 0 & 1 & 2 & $12.17(0.02)$ \\
\hline & 1 & 0 & 1 & 0 & $4.91(0.01)$ \\
\hline & 1 & 0 & 2 & 0 & $9.37(0.02)$ \\
\hline \multirow{4}{*}{ Alanine } & 0 & 0 & 1 & 1 & $9.80(0.01)$ \\
\hline & 0 & 0 & 1 & 2 & $12.62(0.03)$ \\
\hline & 1 & 0 & 1 & 0 & $4.75(0.02)$ \\
\hline & 1 & 0 & 2 & 0 & $8.76(0.02)$ \\
\hline \multirow{4}{*}{ Valine } & 0 & 0 & 1 & 1 & $9.68(0.00)$ \\
\hline & 0 & 0 & 1 & 2 & $12.18(0.01)$ \\
\hline & 1 & 0 & 1 & 0 & $5.32(0.02)$ \\
\hline & 1 & 0 & 2 & 0 & $9.19(0.03)$ \\
\hline \multirow{4}{*}{ Proline } & 0 & 0 & 1 & 1 & $10.65(0.009)$ \\
\hline & 0 & 0 & 1 & 2 & $13.18(0.01)$ \\
\hline & 1 & 0 & 1 & 0 & $5.24(0.03)$ \\
\hline & 1 & 0 & 2 & 0 & $9.98(0.05)$ \\
\hline \multirow{4}{*}{$\beta$-Phenyl alanine } & 0 & 0 & 1 & 1 & $9.20(0.01)$ \\
\hline & 0 & 0 & 1 & 2 & $11.81(0.03)$ \\
\hline & 1 & 0 & 1 & 0 & $4.57(0.02)$ \\
\hline & 1 & 0 & 2 & 0 & $8.25(0.03)$ \\
\hline \multirow{4}{*}{ Methionine } & 0 & 0 & 1 & 1 & $9.23(0.02)$ \\
\hline & 0 & 0 & 1 & 2 & $12.04(0.04)$ \\
\hline & 1 & 0 & 1 & 0 & $4.37(0.03)$ \\
\hline & 1 & 0 & 2 & 0 & $8.75(0.05)$ \\
\hline \multirow{4}{*}{ Isoleucine } & 0 & 0 & 1 & 1 & $9.82(0.01)$ \\
\hline & 0 & 0 & 1 & 2 & $12.46(0.04)$ \\
\hline & 1 & 0 & 1 & 0 & $5.29(0.02)$ \\
\hline & 1 & 0 & 2 & 0 & $8.97(0.03)$ \\
\hline \multirow{4}{*}{ Glutamic acid } & 0 & 0 & 1 & 1 & $9.46(0.01)$ \\
\hline & 0 & 0 & 1 & 2 & $13.54(0.01)$ \\
\hline & 1 & 0 & 1 & 0 & $5.70(0.01)$ \\
\hline & 1 & 0 & 2 & 0 & $9.74(0.02)$ \\
\hline \multirow{4}{*}{ Threonine } & 0 & 0 & 1 & 1 & $9.06(0.009)$ \\
\hline & 0 & 0 & 1 & 2 & $11.07(0.03)$ \\
\hline & 1 & 0 & 1 & 0 & $4.62(0.04)$ \\
\hline & 1 & 0 & 2 & 0 & $8.59(0.05)$ \\
\hline \multirow{4}{*}{ Serine } & 0 & 0 & 1 & 1 & $9.17(0.01)$ \\
\hline & 0 & 0 & 1 & 2 & $11.54(0.03)$ \\
\hline & 1 & 0 & 1 & 0 & $4.57(0.01)$ \\
\hline & 1 & 0 & 2 & 0 & $8.51(0.02)$ \\
\hline \multirow{5}{*}{ Ornithine } & 0 & 0 & 1 & 1 & $10.47(0.03)$ \\
\hline & 0 & 0 & 1 & 2 & $19.27(0.04)$ \\
\hline & 0 & 0 & 1 & 3 & $20.98(0.05)$ \\
\hline & 1 & 0 & 1 & 0 & $4.10(0.04)$ \\
\hline & 1 & 0 & 2 & 0 & $7.30(0.07)$ \\
\hline \multirow{5}{*}{ Cysteine } & 0 & 0 & 1 & 1 & $9.68(0.01)$ \\
\hline & 0 & 0 & 1 & 2 & $17.72(0.02)$ \\
\hline & 0 & 0 & 1 & 3 & $19.35(0.06)$ \\
\hline & 1 & 0 & 1 & 0 & $9.04(0.03)$ \\
\hline & 1 & 0 & 2 & 0 & $17.54(0.06)$ \\
\hline \multirow{6}{*}{ Histidine } & 0 & 0 & 1 & 1 & $9.48(0.01)$ \\
\hline & 0 & 0 & 1 & 2 & $15.76(0.01)$ \\
\hline & 0 & 0 & 1 & 3 & $17.92(0.04)$ \\
\hline & 1 & 0 & 1 & 0 & $6.13(0.08)$ \\
\hline & 1 & 0 & 2 & 0 & $12.09(0.09)$ \\
\hline & 1 & 0 & 1 & 1 & $11.17(0.1)$ \\
\hline
\end{tabular}
rison with con structed theoretical curves. The titration data 


\begin{tabular}{|c|c|c|c|c|c|}
\hline System & $\mathrm{L}$ & $\mathrm{P}$ & q & $\mathrm{r}^{\mathrm{a}}$ & $\log 10 \beta^{b}$ \\
\hline \multirow{5}{*}{ Histamine } & 0 & 0 & 1 & 1 & $9.88(0.03)$ \\
\hline & 0 & 0 & 1 & 2 & $15.94(0.05)$ \\
\hline & 1 & 0 & 1 & 0 & $5.31(0.07)$ \\
\hline & 1 & 0 & 2 & 0 & $10.38(0.09)$ \\
\hline & 1 & 0 & 1 & 1 & $12.46(0.1)$ \\
\hline \multirow{5}{*}{ Pencillamine } & 0 & 0 & 1 & 1 & $10.41(0.02)$ \\
\hline & 0 & 0 & 1 & 2 & $18.29(0.03)$ \\
\hline & 0 & 0 & 1 & 3 & $19.55(0.09)$ \\
\hline & 1 & 0 & 1 & 0 & $9.42(0.04)$ \\
\hline & 1 & 0 & 2 & 0 & $19.54(0.06)$ \\
\hline \multirow{4}{*}{ Imidazole } & 0 & 0 & 1 & 1 & $7.06(0.01)$ \\
\hline & 1 & 0 & 1 & 0 & $2.67(0.06)$ \\
\hline & 1 & 0 & 2 & 0 & $5.12(0.03)$ \\
\hline & 1 & 0 & 3 & 0 & $7.52(0.04)$ \\
\hline \multirow{3}{*}{ Mercaptoethanol } & 0 & 0 & 1 & 1 & $9.52(0.01)$ \\
\hline & 0 & 0 & 1 & 2 & $12.16(0.02)$ \\
\hline & 1 & 0 & 1 & 0 & $7.61(0.01)$ \\
\hline \multirow{3}{*}{ Methylamine } & 0 & 0 & 1 & 1 & $10.07(0.02)$ \\
\hline & 1 & 0 & 1 & 0 & $3.59(0.04)$ \\
\hline & 1 & 0 & 2 & 0 & $6.82(0.09)$ \\
\hline \multirow{3}{*}{ Glycylglycine } & 0 & 0 & 1 & 1 & $8.26(0.009)$ \\
\hline & 0 & 0 & 1 & 2 & $11.44(0.02)$ \\
\hline & 1 & 0 & 1 & 0 & $3.38(0.02)$ \\
\hline \multirow{2}{*}{ Glycinamide } & 0 & 0 & 1 & 1 & $8.06(0.01)$ \\
\hline & 1 & 0 & 1 & 0 & $3.30(0.06)$ \\
\hline \multirow{2}{*}{ Glutamine } & 0 & 0 & 1 & 1 & $8.99(0.03)$ \\
\hline & 1 & 0 & 1 & 0 & $4.15(0.06)$ \\
\hline
\end{tabular}

${ }^{\mathrm{a}} \mathrm{l}, \mathrm{p}$ and $\mathrm{q}$ are the stoichiometric coefficient corresponding to $\mathrm{Zn}(\mathrm{II})$, $\mathrm{P}$, (bioactive ligands) and $\mathrm{H}+$, respectively, ${ }^{\mathrm{b}}$ Standard deviations are given in parentheses

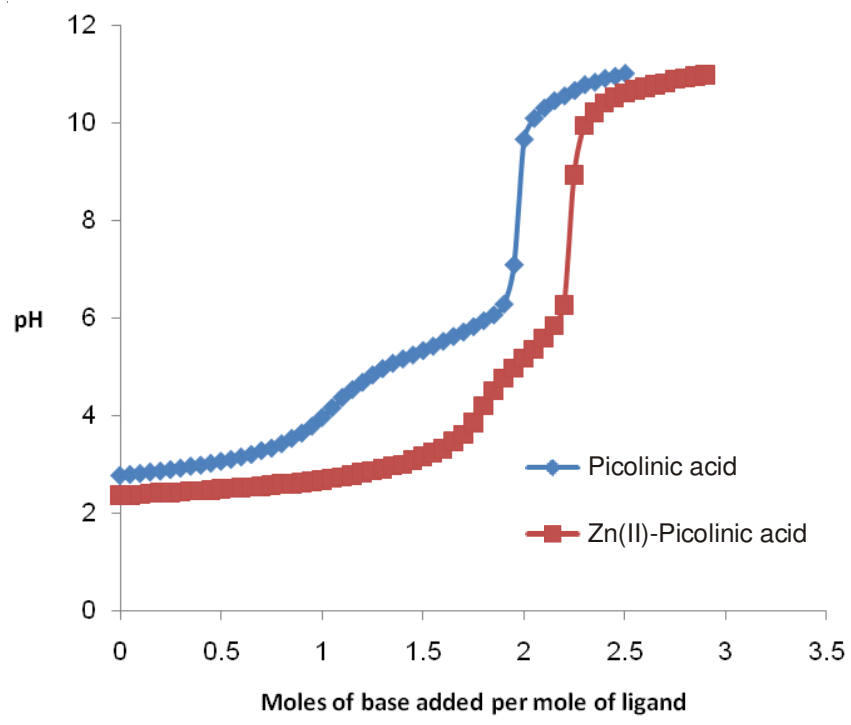

Fig. 2. Potentiometric titration curves of the $\mathrm{Zn}$ (II)-picolinic acid system

of the mixed ligand complexes with picolinic acid and amino acids fit satisfactorily with formation of the species: $\mathrm{Zn}(\mathrm{P})$, $\mathrm{Zn}(\mathrm{P})_{2}, \mathrm{Zn}(\mathrm{L}), \mathrm{Zn}(\mathrm{L})_{2}, \mathrm{Zn}(\mathrm{L})_{3}, \mathrm{Zn}(\mathrm{L}) \mathrm{H}$ and $\mathrm{Zn}(\mathrm{P})(\mathrm{L})$. The mixed ligand complexes of amino acids are more stable than those for the corresponding monodentate methylamine and imidazole complexes, indicating that amino acids most likely coordinates with $\mathrm{Zn}$ (II)-P as a bidentate ligand through the amino and carboxylate groups, rather than as a monodentate ligand. In addition, the stability constant value of the methylamine complex is higher than that of the imidazole complex
(Table-1). The observed extra stability of the methylamine complex may be due to the higher basicity of its amino group. The stability of ternary complexes containing $\alpha$-alanine are found to be lower than those involving glycine, but this behaviour does not follow their basicity as expected. However, it is suggested that steric hindrance caused by the presence of a methyl group on the carbon bearing the amino group ( $\alpha$ alanine) and then the lower stability ${ }^{20}$. In addition to glycine, the phenyl alanine forms a more stable complex than alanine, although the amino group of the phenyl alanine is less basic than that of alanine. Probably due to some stacking interactions between the phenyl group of phenyl alanine and picolinic acid. This will contribute to the stabilization of the formed complex. Threonine and serine forms the $\mathrm{Zn}(\mathrm{P})(\mathrm{L})$ and $\mathrm{Zn}(\mathrm{P})(\mathrm{L}) \mathrm{H}-1$ species. The latter complex is formed through induced ionization of the $\beta$-alcohol group as mentioned in the literature ${ }^{21}$. Our results show that the stability constants of mixed ligand complex of ornithine and histidine are larger than those of $\alpha$ amino acids. It can be understood that ornithine most likely chelates via the two amino groups, whereas histidine interacts with zinc via the amino and imidazole nitrogen atoms (histaminelike). From Table-2, the stability constants of the pencillamine and cysteine complexes are larger of mercaptoethanol and much larger than those for $\alpha$-amino acids, indicating the pencillamine and cysteineinteract with $\mathrm{Zn}$ (II) ion through the amino and deprotonated-SH groups. Fig. 3, shows the distribution diagram for the cysteine complex. The deprotonated

TABLE-2

STABILITY CONSTANTS OF THE TERNARY SPECIES IN THE $\mathrm{Zn}$ (II)-P-L SYSTEMS AT $25^{\circ} \mathrm{C}$ AND I $=0.1 \mathrm{~mol} \mathrm{~L} \mathrm{NaNO}_{3}$

\begin{tabular}{|c|c|c|c|c|c|c|}
\hline System & $\mathrm{L}$ & $\mathrm{P}$ & $\mathrm{q}$ & $\mathrm{r}^{\mathrm{a}}$ & $\log _{10} \beta^{\mathrm{b}}$ & $\Delta \log \mathrm{K}$ \\
\hline Glycine & 1 & 1 & 1 & 0 & $12.30(0.02)$ & 2.27 \\
\hline Alanine & 1 & 1 & 1 & 0 & $12.24(0.02)$ & 2.37 \\
\hline Valine & 1 & 1 & 1 & 0 & $12.27(0.02)$ & 1.38 \\
\hline Proline & 1 & 1 & 1 & 0 & $13.57(0.02)$ & 3.21 \\
\hline$\beta$ phenyl alanine & 1 & 1 & 1 & 0 & $12.28(0.06)$ & 2.59 \\
\hline Methionine & 1 & 1 & 1 & 0 & $12.71(0.02)$ & 3.22 \\
\hline Isoleucine & 1 & 1 & 1 & 0 & $13.17(0.02)$ & 2.76 \\
\hline Glutamic acid & 1 & 1 & 1 & 0 & $13.30(0.04)$ & 2.48 \\
\hline \multirow[t]{2}{*}{ Threonine } & 1 & 1 & 1 & 0 & $13.63(0.01)$ & 3.89 \\
\hline & 1 & 1 & 1 & -1 & $1.80(0.05)$ & \\
\hline Serine & 1 & 1 & 1 & 0 & $13.51(0.03)$ & 3.82 \\
\hline Ornithine & 1 & 1 & 1 & 0 & $17.01(0.02)$ & 7.79 \\
\hline Cysteine & 1 & 1 & 1 & 0 & $20.62(0.06)$ & 6.46 \\
\hline Histidine & 1 & 1 & 1 & 0 & $15.72(0.03)$ & 4.47 \\
\hline Histamine & 1 & 1 & 1 & 0 & $14.55(0.01)$ & 4.12 \\
\hline Pencillamine & 1 & 1 & 1 & 0 & $20.99(0.02)$ & 6.45 \\
\hline Imidazole & 1 & 1 & 1 & 0 & $9.35(0.02)$ & 1.56 \\
\hline Mercaptoethanol & 1 & 1 & 1 & 0 & $17.73(0.03)$ & 5.36 \\
\hline Methylamine & 1 & 1 & 1 & 0 & $10.80(0.03)$ & 2.09 \\
\hline \multirow[t]{3}{*}{ Glycylglycine } & 1 & 1 & 1 & 0 & $11.09(0.05)$ & 2.59 \\
\hline & 1 & 1 & 1 & -1 & $6.00(0.02)$ & \\
\hline & 1 & 1 & 1 & -2 & $-3.48(0.04)$ & \\
\hline \multirow[t]{3}{*}{ Glycinamide } & 1 & 1 & 1 & 0 & $9.52(0.06)$ & 1.1 \\
\hline & 1 & 1 & 1 & -1 & $2.85(0.03)$ & \\
\hline & 1 & 1 & 1 & -2 & $-5.46(0.05)$ & \\
\hline \multirow[t]{3}{*}{ Glutamine } & 1 & 1 & 1 & 0 & $12.33(0.03)$ & 3.06 \\
\hline & 1 & 1 & 1 & -1 & $5.48(0.04)$ & \\
\hline & 1 & 1 & 1 & -2 & $-4.61(0.07)$ & \\
\hline
\end{tabular}




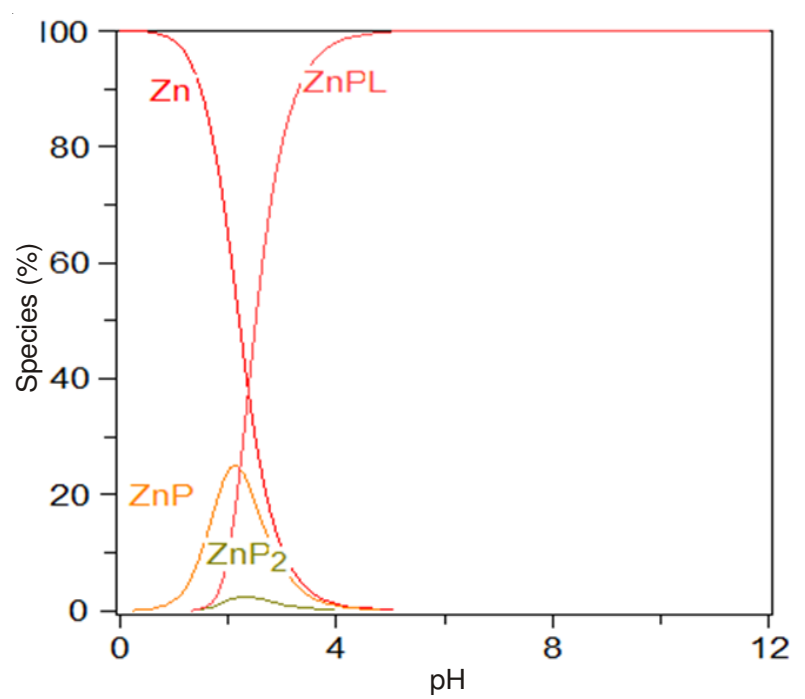

Fig. 3. Concentration distribution of various species with $\mathrm{pH}$ in the ternary $\mathrm{Zn}(\mathrm{II})$-picolinic acid-cysteine system

111-0 complex species predominates with a formation degree amounting to $99.46 \%$ at $\mathrm{pH}=4.77$.

Ternary complexes involving $\mathrm{Zn}$ (II)-picolinic acidpeptides: All the ternary complex formation of amides proceeds also through a simultaneous mechanism and they form the complexes 111-0, 111-1 and 111-2. The amide may form the 111-0 complexes by coordination through the amine and carbonyl groups. On increasing the $\mathrm{pH}$, the coordination sites should switch from carbonyl oxygen to amide nitrogen. Such changes in coordination modes are well documented ${ }^{22}$. The $\mathrm{pK}^{\mathrm{H}}$ values are calculated by the following eqn. 1:

$$
\mathrm{pK}^{\mathrm{H}}=\log 10 \beta_{111-1}-\log 10 \beta_{111-2}
$$

The $\mathrm{pK}^{\mathrm{H}}$ values of the amide group for glycylglycine, glycinamide and glutamine are 9.48, 8.31 and 10.09 respectively. Interestingly, to note that the $\mathrm{pK}^{\mathrm{H}}$ for the glutamine complex is markedly higher than the $\mathrm{pK}^{\mathrm{H}}$ of glycinamide. So this can be explained the formation of a seven membered chelate ring, which would be more strained and less favored. It is noteworthy that the peptide would coordinate to $\mathrm{Zn}$ picolinic acid in entirely different fashions and under normal physiological conditions (pH 6-7). In Fig. 4, the mixed ligand species 1110 starts to form at $\mathrm{pH}-2$ and with increasing of $\mathrm{pH}$, its concentration increases reaching the maximum of $71.89 \%$ at $\mathrm{pH}=5.89$. Increasing of $\mathrm{pH}$ is accompanied by a decrease in 1110 complex concentration and an increase of 111-1 complex concentration. Further increase of $\mathrm{pH}$ are accompanied by a decrease in the 111-1 complex concentration and an increase of the 111-2 complex concentration. Therefore, the species $111-0$ and $111-1$ predominates in the physiological $\mathrm{pH}$ range.

$\Delta \log _{10} \mathrm{~K}$ : The parameter $\Delta \log \mathrm{K}$ values are usually used to indicate the relative stability of the ternary complexes as compared to the binary ones as in the following eqns. 2 and 3:

$$
\begin{gathered}
\mathrm{Zn}(\mathrm{P})+\mathrm{Zn}(\mathrm{L}) \rightleftharpoons \mathrm{Zn}(\mathrm{P})(\mathrm{L})+\mathrm{Zn} \\
\Delta \log _{10} \mathrm{~K}+\log _{10} \beta_{\mathrm{zn}(\mathrm{P}) \mathrm{L}}^{\mathrm{zn}(\mathrm{P})}-\left(\log _{10} \beta_{\mathrm{zn}(\mathrm{P})}^{\mathrm{zn}}+\log _{10} \beta_{\mathrm{zn}(\mathrm{L})}^{\mathrm{zn}}\right)
\end{gathered}
$$

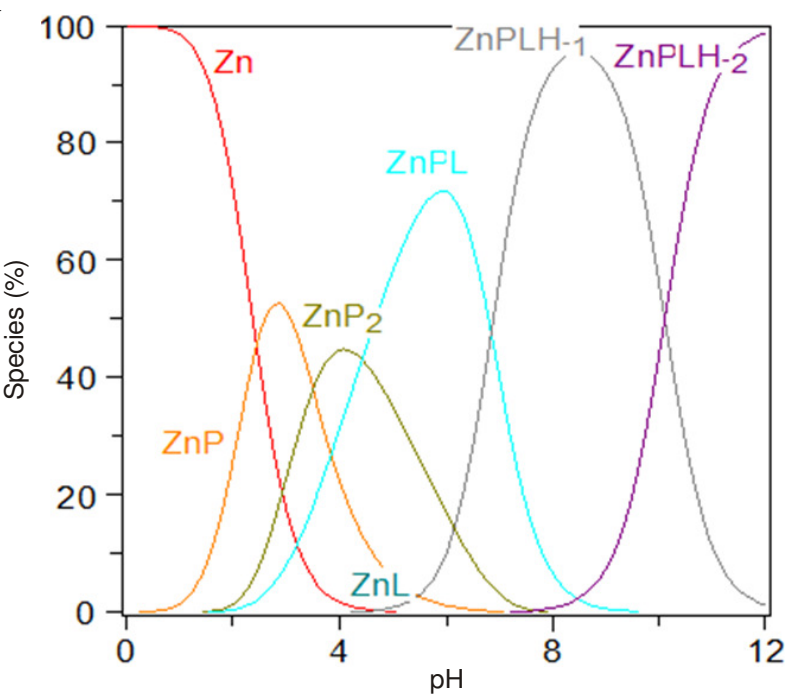

Fig. 4. Concentration distribution of various species with $\mathrm{pH}$ in the ternary $\mathrm{Zn}(\mathrm{II})$-P-glutamine system

The $\Delta \log \mathrm{K}$ values in this paper are invariably positive, where positive values of amino acids and peptides are considered as evidence of enhanced stability as a result of intermolecular ligand-ligand interactions, hydrogen bonding, the $\pi$-back donation effect and/or hydrophobic effects.

\section{Conclusion}

The present investigation describespotentiometric study the formation constants of binary and ternary picolinic acid (P) complexes involving $\mathrm{Zn}$ (II) and some bioactive ligands in water solutions at $25^{\circ} \mathrm{C}$ and ionic strength $0.1 \mathrm{~mol} / \mathrm{L} \mathrm{NaNO}_{3}$ by HYPERQUAD program. Beside, the relative stabilities of each ternary complexes are compared with those of the corresponding binary complexes. Additionally, the concentration distribution curves of the various complex species existing in solution were evaluated.

\section{ACKNOWLEDGEMENTS}

The authors extended their appreciation to the Deanship of Scientific Research at King Saud University for funding the work through the research group project No. RGP-VPP-062.

\section{REFERENCES}

1. R.S. Grant, S.E. Coggan and G.A. Smythe, Int. J. Tryptophan Res., 2, 71 (2009).

2. H. Rosas, L.E. Sarmiento, M. Rodríguez and V. Lubes, J. Solution Chem., 39, 1021 (2010).

3. A. Syamal and P.K. Mandal, Transition Metal Chem., 3, 292 (1978).

4. S.M. Lee, S.K. Ryu, C.H. Jung, H.J. Won and W.Z. Oh, Carbon, 40, 329 (2002).

5. B. Saha, M. Das, R.K. Mohanty and A.K. Das, J. Chinese Chem. Soc., 51, 399 (2004).

6. D. Pijper, P. Saisaha, J.W. de Boer, R. Hoen, C. Smit, A. Meetsma, R. Hage, R.P. van Summeren, P.L. Alsters, B.L. Feringa and W.R. Browne, Dalton Trans., 39, 10375 (2010).

7. G. Lubes, M. Rodríguez and V. Lubes, J. Solution Chem., 39, 1134 (2010).

8. H. Imam, B. Kumar and M. Shafayat, Orient. J. Chem., 27, 287 (2011).

9. W. Mangesh, W. Kailas and S. Shriram, Res. J. Chem. Environ., 17, 53 (2013).

10. T.L. Varadinova, P.R. Bontehev, C.K. Nachev and S.A. Shiskov, J. Chemother., 5, 3 (1993). 
11. N.E. Chakov, R.A. Collins and J.B. Vincent, Polyhedron, 18, 2891 (1999).

12. R. March, W. Clegg, R.A. Coxall, L. Cucurull-Sánchez, L. Lezama, T. Rojo and P. González-Duarte, Inorg. Chim. Acta, 353, 129 (2003).

13. Z. Vargová, J. Kotek, J. Rudovský, J. Plutnar, R. Gyepes, P. Hermann, K. Györyová and I. Lukes, Eur. J. Inorg. Chem., 2007, 3974 (2007).

14. M. Aljahdali and A.A. El-Sherif, J. Solution Chem., 41, 1759 (2012).

15. F.J. Welcher, The Analytical Uses of Ethylenediaminetetraacetic Acid. Van Nostrand, Princeton, USA, edn 4, p. 143 (1965).
16. A. Jacques, (Complex Ion in Aqueous Solutions), Longmans, London (1914).

17. P. Gans, A. Sabatini and A. Vacca, Talanta, 43, 1739 (1996).

18. L. Alderighi, P. Gans, A. Ienco, D. Peters, A. Sabatini and A. Vacca, Coord. Chem. Rev., 184, 311 (1999).

19. K. Suzuki and K. Yamasaki, Naturwissenschaft, 44, 396 (1957).

20. J.I. Liangnian and L.E. Xueyi, Chin. Sci. Bull., 47, 1 (2002).

21. K. Suzuki and K. Yamasaki, Naturwissenschaft, 44, 396 (1957).

22. M.C. Lim, J. Chem. Soc., Dalton Trans., 15 (1977). 